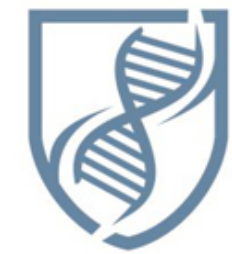

Journal of Bioscience and Applied Research
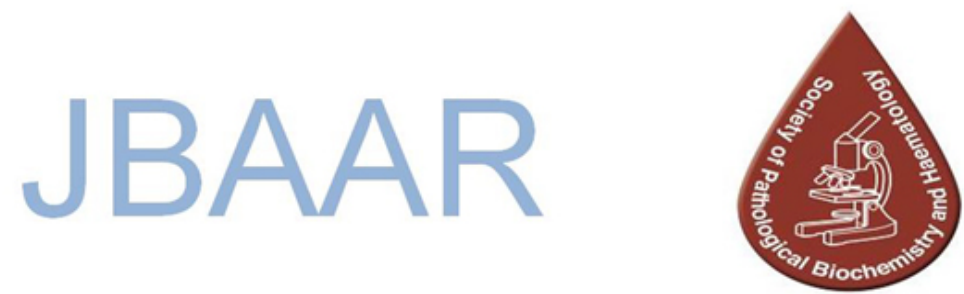

\title{
North African sharptooth catfish Clarias gariepinus: In silico analyses for genetic expansion of a peculiarly successful catfish species in and out of its African homelands
}

Khaled Mohammed-Geba

Molecular Biology and Genetic Engineering Division, Department of Zoology, Faculty of Sciences, Menoufia University, Shebin El- Kom, Menoufia, Egypt.

Tel.: 002-0482235690, fax.: 002-0482235689

(Email: Khaledspain@yahoo.com)

\begin{abstract}
The African sharptooth catfish Clarias gariepinus originated from Africa, but its sturdiness and resistance to different environmental conditions enabled it to spread to almost all continents of the world. To develop effective conservation strategies for $C$. gariepinus, the connection patterns of its geographically related and isolated strains should be precisely described. For this purpose, 65 sequences for cytochrome oxidase subunit 1 (CO1) mitochondrial gene were retrieved from GenBank database. Common and unique haplotypes, average numbers of nucleotide substitutions $\left(\mathrm{D}_{\mathrm{xy}}\right)$, fixation indices $\left(\mathrm{F}_{\mathrm{ST}}\right)$, neutrality and expansion, phylogeny, and haplotype network analyses were all identified. 13 different haplotypes were found, most of which are related to an African haplotype mainly found in Nigeria. Other African, Asian, and South American haplotypes were detected, with the South American and some Asian haplotypes showing the greatest diversion from the main African one. The Nigerian population of C. gariepinus seems to be the most rapidly expanding one, due to the highest frequency of singletone haplotypes among all studied populations. Our results agreed with the knowledge about the world-wide propagation of C. gariepinus recorded in the Food and Agriculture Organization introduced aquatic species database and other related reports, what may confirm the effectiveness of such molecular markers and bioinformatic tools for tracking the origin and movement of the $C$. gariepinus out of Africa.
\end{abstract}

Keywords: Africa,Clarias gariepinus, CO1, molecular markers, population genetics.

\section{Introduction}

Africa is the hosting continent for many catfish species, belonging to varying siluriform families that inhabit its inland water since very long time, mainly Amphiliidae (loach catfishes), Anchariidae (Malagasy catfishes), Ariidae (shark catfishes), Austroglanididae (southern rock catfish), Bagridae (naked catfishes), Clariidae (the air-breathing or walking catfishes), Claroteidae (giraffe catfishes), Malapteruridae (electric catfishes), Mochokidae (upside down catfishes), and Schilbeidae (glass catfishes) (Zhang, 2011; www.Fishbase.org). However, catfishes are wellknown in all continents on earth; with a fossil record extending back to the late Cretaceous found all around the world except Australia (Nilson, 2006). Siluriformes are believed to be the second primitive-most group in the taxon Otophysi, newer than Cypriniformes but elder than Characiformes and Gymnotiformes. Many evidences point to that the origin of siluriformes is the new world, more strictly South America. The oldest siluriform fossil discovered so far was in Argentina. Furthermore, the most apomorphic catfish species that are adapted to sea water are also found in South America; that are Ariidae and Plotosidae. This latter finding led to a commonly accepted hypothesis that the evolution of catfish taxa proceeded in South America, before the separation from Africa. Separation of Australia might be earlier than the completeness of this catfish evolution event due to the complete absence of siluriformes from there. Moreover, the most primitive families are found in the New World also: the extinct Diplomystidae in Argentina and Chile, and the 
fossil Hypsidoridae in USA (Briggs, 2005). In the modern era, world siluriformes are categorized in 478 genera containing 3093 species. Most of them are freshwater inhabitants, but only 2 families are marine, as mentioned before.

In terms of modern ecological states and economies, catfishes are among the relatively low-value species, yet contribute well to the international aquaculture products trade (FAO, 2014). The North African catfish Clarias gariepinus gains special popularity in Africa and other areas where it is cultivated due to its tolerance to extreme environmental conditions, capability of air breathing under dry conditions and omnivorousity (FAO, 2010). Since the start of the millennia, its production increased more than 30 folds. Nigeria dominates the production of North African catfish in the world. Netherlands, Italy, Hungary, Kenya, Syria, Brazil, Cameroon, Mali and South Africa account also for significant productions. The fish was also introduced to Jordan, Turkey, Lebanon, and other Asian and South American countries (FAO, 2010).

To develop effective conservation strategies for the North African catfish and obtain a better understanding for its physiological responses under different rearing conditions, the connections of its different, geographically related and isolated strains should be precisely described by detailed genealogical studies based on DNA markers. The mitochondrial enzyme cytochrome $\mathrm{C}$ oxidase subunit 1 (CO1) gene has been particularly popular for estimating relationships among closely allied taxa and efficient elucidation of biological diversity.

DNA barcode technology, using short CO1 sequences, has been proposed as a method for enabling rapid, accurate detection and identification of species. This method is accepted as a standard for characterization of life forms in numerous groups of living organisms, i.e. DNAfingerprinting of these organisms. It is now being proposed as a method for cataloguing life and developing a comprehensive species-specific sequence library for all eukaryotes (Marshall, 2005; Hajibabaei et al. 2007; Yu et al, 2011). This approach will significantly broaden the application of DNA barcoding in biodiversity studies. DNA barcoding is increasingly used in studies with the North African Catfish, for example, in order to detect species substitution for market control and combating the unsustainable commercial use of vulnerable species (Wong et al. 2011), to identify commercially important species in the fish market (Keskin and Atar, 2013), and to infer the phylogenetic relationships with other siluriform species (Indu et al. 2012). The aim of this work is to use the CO1 partial gene sequences to understand the spread of $C$. gariepinus in and out of Africa, and the relationship between its different world-wide populations and their possible genetic interactions, using several in silico bioinformatic analyses.

\#

\section{Materials and Methods}

Sixty five (65) Clarias gariepinus cytochrome A phylogenetic, neighbor-joining tree was calculated

oxidase 1 gene $(\mathrm{CO} 1)$ nucleotide sequences available by progressive aligning the $65 \mathrm{CO} 1$ nucleotide in the GenBank database were retrieved. These sequences came from 65 C. gariepinus samples that were obtained, DNA-extracted, and barcoded by $\mathrm{CO} 1$ PCRs in different countries, as follows: 5 from Brazil, 2 from Indonesia, 17 from Nigeria, 11 from Thailand, 21 from Turkey, 7 from India, 1 from Syria and 1 from Ethiopia. The sequences were uploaded to the program MEGA6 (Tamura et al. 2013) and aligned using ClustalW (Thompson et al. 1994). The sequences were then trimmed to obtain a final common zone of a 513 base-long gene fragment. Best DNA substitution model was determined by ModelTest procedure integrated in MEGA 6 Software. Based on this, a neighbor-joining phylogenetic tree was constructed. 1,000 bootstraps were used to enhance the quality of the test.

The alignment was then uploaded to DNAsp 5.0 Software (Rozas et al. 2003) in order to determine the haplotypes existing in common and separately withtin the selected CO1 fragment, together with haplotype (h) and nucleotide $(\pi)$ diversity indices. Also, recent population expansions as detected by the increasing diversity of haplotypes in a given population and the homogenous patterns of pairwise differences among them were inferred from calculating the index of raggedness, $r$ (Harpending, 1994) and $R_{2}$ parameter (Ramos-Onsins and Rozas, 2002).

The haplotypes determined through DNAsp 5.0 Software were then uploaded to the program Network 4.6.1.2 (Bandelt et al. 1999) in order to draw medianjoining haplotype network and further demonstrate the interrelationships among different haplotypes.

Average number of nucleotide substitutions per site between populations, pairwise genetic differences between samples using the F-statistics, based on haplotypes frequencies, and the $\mathrm{F}_{\mathrm{st}}$ value, based on haplotypes frequencies and sequence divergences between them-were all estimated using the software ARLEQUIN 3.5.1.1 (Excoffier and Lischer 2010). Components of variability among samples were partitioned using the analysis of molecular variance (AMOVA, Excoffier et al. 1992), integrated to ARLEQUIN 3.5.1.1, after merging the sequences according to the results of the phylogenetic tree. Moreover, neutrality analysis was performed by determining the D test statistic of Tajima (1989), and the Fs statistic of $\mathrm{Fu}(\mathrm{Fu}, 1997)$, whose negative values arise due to the excess of low-frequency haplotypes that arise from selection or rapid population growth (Tajima, 1989; Borrell et al. 2012).

\section{Results}


sequences of C. gariepinus available in the GenBank inferred from the constructed median-joining network database. These 65 sequences belong to African (Figure 3).

catfish cultured or fished in different geographical Also, the median-joining network and the values of locations. The phylogram showed the clustering of average numbers of nucleotide substitutions $\left(D_{\mathrm{xy}}\right)$ Turkish samples of catfish with African samples from showed that the major African haplotype (H4) ,the Nigeria and Ethiopia. In the same branch exists a main Nigerian one, is separated from the major Asian single Syrian, single Indian and single Thailand CO1 (Thailand-Indian) haplotypes H8 by 8 mutational sequences. However, most of the Thailand and Indian events and $1.5 \%$ sequence divergence $\left(D_{x y}=\right.$ samples belong to a different clade, that contains in 0.01559). A star-shaped haplotypes network was other subclade the Brazilian samples and single found around the African main haplotypes. In this Indonesian one (Figure 1).

Using the software DNAsp, the haplotypes and their distribution in different geographical areas were investigated. The result was 13 different haplotypes. Another phylogenetic tree for haplotypes data only was constructed (Figure 2), together with the median joining network (Figure 3). A single haplotypes could be detected as the common one between Nigeria, Ethiopia, Syria, and Thailand.

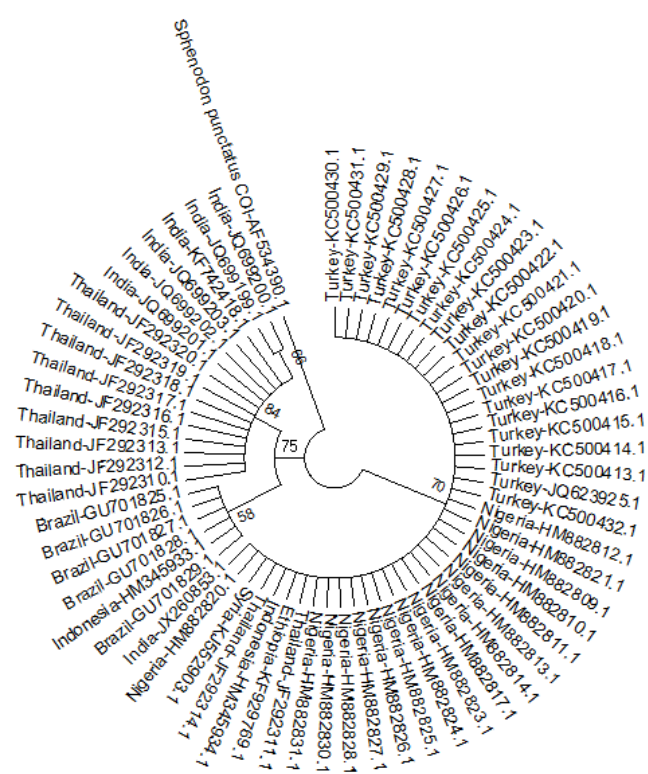

Figure 1: Neighbor-joining phylogenetic tree for all Clarias gariepinus $\mathrm{CO} 1$ partial sequence common fragment present in GenBamk database from different countries. Bootstrap value is shown on each branch. Tuatara (Sphenodon punctatus, Order: Reptilia) CO1 was used as an outgroup.

Most other Thailand sequences belonged to the haplotype 8, which included also an Indian sequence and was very closely related to the other Indian haplotypes. On the other hand, haplotypes 1 (the Brazilian), 2 (the Indonesian), 10, 11 (the Indians) and 8 seem to be very distant from the African and other Asian haplotypes, with several genetic changes occurring in the $\mathrm{CO} 1$ between these groups, as
"African" network, three other Nigerian haplotypes (H5, H6, H7) emerge from the main African one, through mutations at sites 486, 285, $159\left(D_{x y}=\right.$ $0.00195)$. Singleton haplotypes from India $\left(H 13, D_{x y}=\right.$ 0.00587), Thailand (H9, $\left.\mathrm{D}_{\mathrm{xy}}=0.00390\right)$ and Indonesia $\left(\mathrm{H} 3, \mathrm{D}_{\mathrm{xy}}=0.00195\right)$ also emerged from the African main haplotypes with 3 (sites 11, 16, 39), 2 (sites 10, 12 ) and 1 (site 3 ) mutational events, respectively.

It appears clearly that at least two introductions of $C$. gariepinus took place in Asia from the African

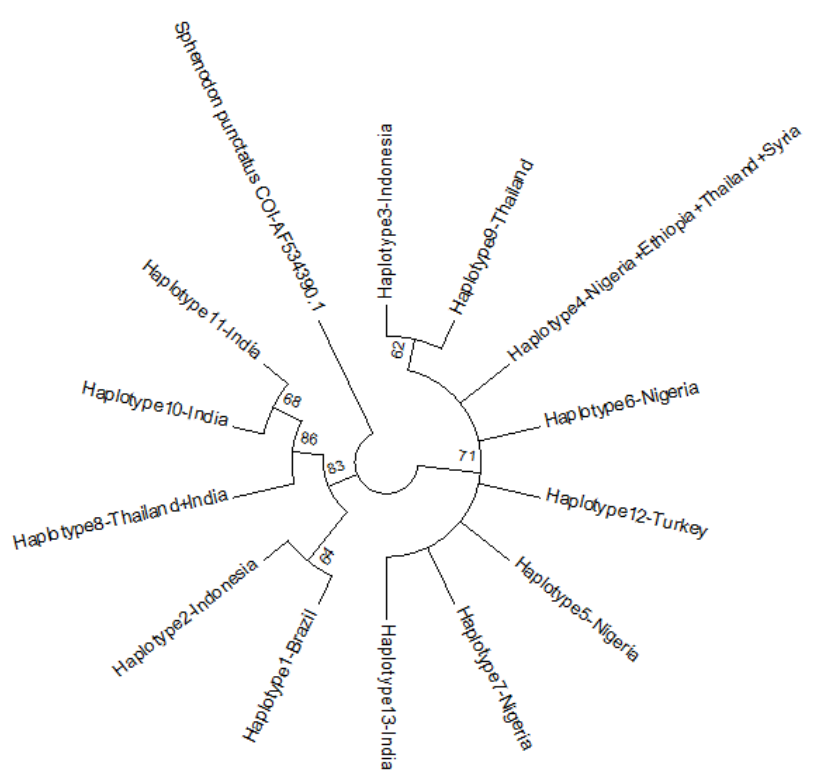

Figure 2: Reduced haplotype Neighbor-joining phylogenetic tree for all Clarias gariepinus $\mathrm{CO} 1$ sequence common fragment present in GenBamk database from different countries. Bootstrap value is shown on each branch. Tuatara (Sphenodon punctatus, Order: Reptilia) CO1 was used as an outgroup.

haplotypes (H4), a recent one from which haplotypes 3,9 , and 13 emerged, and a more elder one at which the commonest asian haplotypes (H8) and two other singletons (H10 and H11) appeared. Furthermore, the Brazilian haplotypes are in closer proximity to the Asian populations than to the African ones under the coverage of this study, especially to the Indonesian $\mathrm{H} 2$ and to the Thailand/Indian major Asian haplotypes 
(H8). Table 1 shows the basic haplotypes and

1.44633, $\mathrm{P}=0.05300)$ and Thailand $(-0.53907$, nucleotide diversity indexes and Table 2 details the $\mathrm{F}_{\mathrm{st}} \mathrm{P}=0.32700$ ). Moreover, it seems that C. gariepinus values and their significances based on haplotypes populations in these countries are recently expanding frequencies between the studied populations, due to the low, non-significant raggedness and low $\mathrm{R}_{2}$ alongside with average number of nucleotide values (Ramos-Onsins and Rozas, 2002). The lowest substitutions among populations, $\mathrm{D}_{\mathrm{xy}}(\mathrm{Nei}, 1987)$. value for $R_{2}$ was found in the Nigerian population, in AMOVA analysis of population structuring of $C$. correspondence to the results of the comparison of gariepinus proceeded after merging the sequences haplotypes distribution by Fu's statistic that showed a according to the phylogenetic tree. The studied real significant sign of population expansion only in populations of $C$. gariepinus seem to be greatly Nigeria $(F s=-1.93559, \mathrm{P}=0.01000)$. The differences separated on space and time and without a clear signal between both neutrality statistics can be attributed to of current mixing between them, (fixed: global $\mathrm{F}_{\mathrm{st}}=$ that $\mathrm{Fu}$ test is more powerful than Tajima's (Ramos0.81, $\mathrm{P}=0.00000$ ). Testing the frequency of segregated Onsins and Rozas, 2002; de Jong et al. 2011). Also, nucleotide sites by Tajima's statistic, D values were

$\mathrm{Fu} \mathrm{F}_{\mathrm{s}}$ statistic behavior was shown to be superior for large sample sizes while $R_{2}$ is better for smaller numbers (Ramos-Onsins and Rozas, 2012).

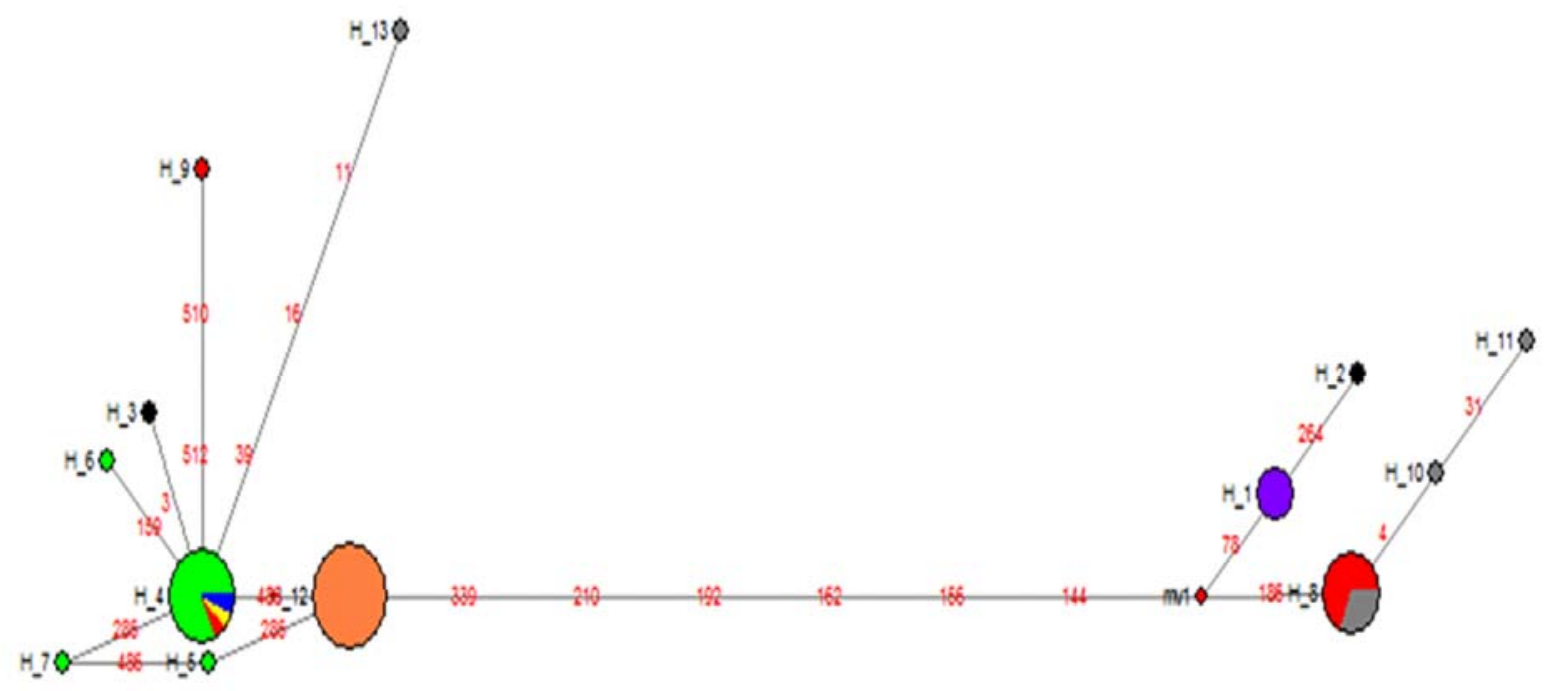

Fig 3. Median-joining haplotype network for COI in C. gariepinus. The branch length is proportional to the number of substitutions. Red colours represent the polymorphic sites that differ among haplotypes. Circles represent haplotypes and their diameters are proportional to the haplotype frequencies. Circles with green colour: Nigeria, red colour: Thailand, blue colour: Syria, yellow colour: Ethiopia, violet colour: Brazil, black colour: Indonesia, grey colour: India and havan colour: Turkey. 
Table 1: different haplotype and nucleotide diversity parameters found in the surveyed populations of African catfish C. gariepinus. $\mathrm{N}$ : Sample sizes, $\mathrm{n}_{\mathrm{h}}$ : number of haplotypes, $\mathrm{n}_{\mathrm{hs}}$ : number of site-specific haplotypes, $\mathrm{h}_{\mathrm{d}} \pm \mathrm{s}$.d: haplotype diversity with standard deviation, and $\pi \pm$ s.d: nucleotide diversity with standard deviation.

\begin{tabular}{|c|c|c|c|c|c|c|c|c|}
\hline $\begin{array}{c}\text { Sample } \\
\text { Origin }\end{array}$ & $\mathrm{N}$ & $\mathrm{n}_{\mathrm{h}}$ & $\mathrm{n}_{\mathrm{hs}}$ & $\mathrm{h}_{\mathrm{d}} \pm \mathrm{s} . \mathrm{d}$ & $\begin{array}{c}\mathrm{n}^{\mathrm{o}} \text { polymprphic } \\
(\text { segregated }) \text { loci }\end{array}$ & $\mathrm{r}$ & $\mathrm{R}_{2}$ & $\pi \pm \mathrm{s.d}$ \\
\hline Nigeria & 17 & 4 & 3 & $0.331 \pm 0.143$ & 3 & $\begin{array}{c}0.22908 \\
(\mathrm{p}=0.6200)\end{array}$ & 0.1135 & $0.0089 \pm 0.00043$ \\
\hline Thailand & 11 & 3 & 1 & $0.345 \pm 0.172$ & 10 & $\begin{array}{c}0.53620 \\
(\mathrm{p}=0.76000)\end{array}$ & 0.1430 & $0.172 \pm 0.00279$ \\
\hline India & 7 & 4 & 3 & $0.714 \pm 0.181$ & 13 & $\begin{array}{c}0.09977 \\
(\mathrm{p}=0.92000)\end{array}$ & 0.2934 & $0.00764 \pm 0.00415$ \\
\hline Turkey & 21 & 1 & 1 & 0 & 0 & --- & --- & 0 \\
\hline Brazil & 5 & 1 & 1 & 0 & 0 & --- & --- & 0 \\
\hline Indonesia & 2 & 2 & 2 & $1 \pm 0.5$ & 10 & --- & $0.01949 \pm 0.00975$ \\
\hline Syria & 1 & 1 & 0 & 0 & 0 & --- & 0 \\
\hline Ethiopia & 1 & 1 & 0 & 0 & 0 & --- & 0 \\
\hline
\end{tabular}

Table 2: Below the diagonal: pairwise $\mathrm{F}_{\mathrm{st}}$ for haplotypes frequencies (standard AMOVA haplotypes format) $(\mathrm{p}<0.05)$. Above the diagonal, average number of nucleotide substitutions, Dxy (Nei, 1987).

\begin{tabular}{|c|c|c|c|c|c|c|c|c|}
\hline \multirow[b]{2}{*}{$\begin{array}{c}\text { Sample } \\
\text { Origin }\end{array}$} & \multicolumn{8}{|c|}{ Global $\mathrm{F}_{\mathrm{st}}=0.80119 *(\mathrm{p}=0.0000)$} \\
\hline & Nigeria & Thailand & India & Turkey & Brazil & Indonesia & Syria & Ethiopia \\
\hline Nigeria & & 0.01338 & 0.01536 & 0.00218 & 0.01582 & 0.01009 & 0.00046 & 0.00046 \\
\hline Thailand & $\begin{array}{l}0.78428 \\
\left(0.00000^{*}\right)\end{array}$ & & 0.00630 & 0.01187 & 0.00638 & 0.01170 & 0.01311 & 0.01311 \\
\hline India & $\begin{array}{l}0.80648 \\
(0.00000 *)\end{array}$ & $\begin{array}{l}-0.06293 \\
(0.53153)\end{array}$ & & 0.01370 & 0.00727 & 0.01314 & 0.01510 & 0.01510 \\
\hline Turkey & $\begin{array}{l}0.81495 \\
(0.00000 *)\end{array}$ & $\begin{array}{l}0.82441 \\
\left(0.00000^{*}\right)\end{array}$ & $\begin{array}{l}0.85328 \\
\left(0.00000^{*}\right)\end{array}$ & & 0.01365 & 0.00975 & 0.00195 & 0.00195 \\
\hline Brazil & $\begin{array}{l}0.95564 \\
(0.00000 *)\end{array}$ & $\begin{array}{l}0.43012 \\
(0.00000 *)\end{array}$ & $\begin{array}{l}0.41164 \\
\left(0.00000^{*}\right)\end{array}$ & $\begin{array}{l}1.00000 \\
\left(0.00000^{*}\right)\end{array}$ & & 0.00975 & 0.01559 & 0.01559 \\
\hline Indonesia & $\begin{array}{l}0.68160 \\
(0.02703 *)\end{array}$ & $\begin{array}{l}0.22900(0 . \\
05405)\end{array}$ & $\begin{array}{l}0.17398 \\
(0.04505)\end{array}$ & $\begin{array}{l}0.83267 \\
(0.00901 *)\end{array}$ & $\begin{array}{l}0.47368 \\
(0.06306)\end{array}$ & & 0.00975 & 0.00975 \\
\hline Syria & $\begin{array}{l}-0.93750 \\
(0.99099)\end{array}$ & $\begin{array}{l}0.55676(0 . \\
99099)\end{array}$ & $\begin{array}{l}0.49383 \\
(0.99099)\end{array}$ & $\begin{array}{l}1.00000 \\
(0.99099)\end{array}$ & $\begin{array}{l}1.00000 \\
(0.99099)\end{array}$ & $\begin{array}{l}-1.00000 \\
(0.99099)\end{array}$ & & \\
\hline Ethiopia & $\begin{array}{l}-0.93750 \\
(0.99099)\end{array}$ & $\begin{array}{l}0.55676 \\
(0.99099)\end{array}$ & $\begin{array}{l}0.49383 \\
(0.99099)\end{array}$ & $\begin{array}{l}1.00000 \\
(0.99099)\end{array}$ & $\begin{array}{l}1.00000 \\
(0.99099)\end{array}$ & $\begin{array}{l}-1.00000 \\
(0.99099)\end{array}$ & $\begin{array}{l}0.00000 \\
(0.99099)\end{array}$ & \\
\hline
\end{tabular}




\section{Discussion}

The North African sharptooth catfish, Clarias gariepinus, occupies a very wide geographical range in Africa, from the Nile in the North to the Orange River between Namibia and South Africa in the South. Aquaculture activities in different regions in the world led to its wide spread, the expansion supported by its sturdiness and diversified feeding habits. It was recorded as an invasive species in many countries, having negative impacts on the aquatic, amphibian, and avian biota (Cambray, 2003). Among the important economic fish that are threatened by catfish introduction are the eels and the bass (Cambray, 2003). Even massive introgression between $C$. gariepinus and the Thailand walking catfish, C. macrocephalus is found in Thailand, representing a serious concern for the balance of the normal populations of C. macrocephalus (Na-Nakorn et al. 2014).

C. gariepinus started to gain popularity for aquaculture all over the world since 1990s. In Brazil, and since its market interest was low, the species was used as sport fish. Uncontrolled escapes happened and the fish propagated to the Amazon River branches and lakes, supported by the comparatively-small sizes of the native catfish species, the highly predative nature of C. gariepinus, its capacity to grow to massive sizes, and tolerance to extreme environmental conditions. Hence, it represents a top invader there (Vitule et al. 2006). Our phylogenetic and median joining network data showed a close proximity between the Brazilian C. gariepinus samples and the Asian counterparts, especially the Indonesian ones. This agreed with FAO introduced aquatic species database (website is shown in the references appendix below) which indicates that South Africa was the source of C. gariepinus introduced to both Indonesia and Brazil in 1986 by the private sector for aquaculture purposes.

On the other hand, FAO introduced aquatic species database did not indicate the African origin of Thai $C$. gariepinus samples, but showed that the introduction was from Laos in the Southeast Asia, to the South of China. Our results exhibited the division of Thailand sequences into three groups; one of them is closely related to the Indian C. garipenus populations, which is also documented in the FAO introduced species database with Thailand as the funding population, other is directly related to the Nigerian and Ethiopian ancestors, and the third group seems to be more related to a second Indonesian one, although both of them seem to be separated from the other Asian clade. It's noteworthy to mention that, besides North Africa,
C. gariepinus was also introduced to Thailand from Netherlands.

A common haplotype was shared between Nigerian, Ethiopian, and Syrian C. gariepinus populations. Although the source of C. gariepinus in Turkia and Syria is under debate and still unclear, the phylogenetic analysis showed a close relationship between this common haplotype and the Turkish one (Figure 2). Using another mitochondrial marker, the control region, the recent Syrian C. gariepinus populations were shown to belong to the Nile directly, although a possible "introduction" of this fish as an exotic species is not historically documented. Furthermore, the fossil remains of Clarias gariepinus found in Syria and Turkey, pointed to a possible North- or Northeastern migrations in the Pleistocene from the lower Nile system, either through freshwater connections now submerged or on massive freshwater runoff from the Nile during wet palaeoclimatic periods; or through the slip tectonic fault between the Gulf of Aqaba, via the Jordan, Litani, and Orontes valleys (Arndt et al. 2003).

Other important aspect in the population genetics of Clarias gariepinus is its capacity to hybridize with other species from the same genus Clarias, or with other genera belonging to his family (Clariidae). Some of these hybrids are well-known economically, especially for some possibilities in the hybrids to grow faster than the parent, native species. Some cases of escapes from farms of these hybrids to the wild were recorded, what may cause some degree of genetic introgression and hence possible changes on the distribution of different conservation units of Clarias gariepinus in the wild as normally expected by preference to certain environmental conditions over the others. The most well known natural or artificial crossings for production these hybrids are the ones found between Heterobranchus bidorsalis X Clarias gariepinus (Adeyemo et al. 1994), $H$. longifilis X C. gariepinus (Teugels et al. 1992), C. macrocephalus X C. gariepinus (Na-Nakorn et al. 2004), and C. batrachus X C. gariepinus (Giri et al. 2003).

In conclusions, Clarias gariepinus shows good success out of Africa, especially in Asia, although a funding population like the Nigerian one seems to still the most capable of expansion. Although the Mediterranean populations are more directly related to the African, especially the western, populations, the Asian and American populations seem to be more subjected to international transfers and introductions. Finally, the used bioinformatic analyeses of phylogenetic trees, median joining networks, and 
AMOVA, basing on sequences published on GenBank database, are shown to be efficient in silico tools for identifying the spread of the North African catfish in the world as their results were very similar to what found in the FAO introduced aquatic species database and what found in the scientific literature related to this issue. The great expansion in the world genetic databases, e.g. GenBank, may provide valuable tools for proper identification of cosmopolitan species population structures. This may be helpful during the planning for adequate management of different conservation units belonging to the same species and/or taxonomic group.

\section{Acknowledgments}

The author greatly appreciates the role of Dr. Alba ArduraGutierrez and Dr. Marta Muñóz-Colmenero (Department of Functional Biology, Universidad de Oviedo, Spain) for their precious help during the development of this work. Also, I would like to thank the anonymous reviewers and editors of the Journal of Bioscience and Applied Research in the enhancement of the work quality by their suggestions.

\section{References}

Adeyemo, A.A., Oladosu, G.A. and Ayinla, A.O. 1994. Growth and survival of fry of African catfish species, Clarias gariepinus Burchell, Heterobranchus bidorsalis Geoffery and Heteroclarias reared on Moina dubia in comparison with other first feed sources. Aquaculture, 119 (1): $41-45$.

Arndt, A., Van Neer, W., Hellemans, B., Robben, J., Volckaert, F. and Waelkens, M. 2003. Roman trade relationships at Sagalassos (Turkey) elucidated by ancient DNA of fish remains. Journal of Archaeological Science, 30: 1095-1105.

Bandelt, H.J., Forster, P. and Röhl A. 1999. Median-joining networks for inferring intraspecific phylogenies. Molecular Biology and Evolution, 16(1): 3748.

Borrell, Y.J., Piñera, J.A., Sánchez Prado, J.A. and Blanco, G. 2012. Mitochondrial DNA and microsatellite genetic differentiation in the European anchovy Engraulis encrasicolus L. ICES Journal of Marine Science; 69(8): 1357-1371.

Briggs, J.C. 2005. The biogeography of otophysan fishes (Ostariophysi: Otophysi): a new appraisal. Journal of Biogeography 32 (2): 287-294.

Cambray, J.A. 2003. The need for research and monitoring on the impacts of translocated sharptooth catfish, Clarias gariepinus, in South Africa. African Journal of Aquatic Science 28 (2): 191-195.

De Jong, M.A., Wahlberg, N., van Eijk, M., Brakefield, P.M. and Zwaan, B.J. 2011. Mitochondrial DNA signature for range-wide populations of Bicyclus anynana suggests a rapid expansion from recent refugia.
PLoS One, 6(6): e21385.

Excoffier, L. and Lischer, H.E. 2010. Arlequin suite ver 3.5: a new series of programs to perform population genetics analyses under Linux and Windows. Molecular Ecology Resources, 10(3): 564-567.

Excoffier, L., Smouse, P.E. and Quattro, J.M. 1992. Analysis of molecular variance inferred from metric distances among DNA haplotypes: application to human mitochondrial DNA restriction data. Genetics, 131(2): 479491.

FAO 2010-2015. Clarias gariepinus. Cultured Aquatic Species Information Programme. Text by Pouomogne, V. In: FAO Fisheries and Aquaculture Department [online]. Rome. [Last accessed in 12 June 2015].

http://www.fao.org/fishery/culturedspecies/Clarias gariepi nus/en.

FAO introduced aquatic species database: http://www.fao.org/fi/website/FISearchAction.do;jsessionid =9F9AF937E01E238DD366AEAFEDEE5594.

FAO 2014. The state of world fisheries and aquaculture. http://www.fao.org/3/a-i3720e.pdf.

Fu, Y.X. 1997. Statistical tests of neutrality of mutations against population growth, hitchhiking and background selection. Genetics, 147(2): 915-25.

Giri, S.S., Sahoo, S.K., Sahu, A.K. and Meher, P.K 2003. Effect of dietary protein level on growth, survival, feed utilisation and body composition of hybrid Clarias catfish (Clarias batrachus $\times$ Clarias gariepinus). Animal Feed Science and Technology 104 (1-4): 169-178.

Hajibabaei, M., Singer, G.A., Clare, E.L. and Hebert, P.D. 2007. Design and applicability of DNA arrays and DNA barcodes in biodiversity monitoring. BMC Biology, 5: 24.

Harpending, H. 1994. Signature of ancient population growth in a low-resolution mitochondrial DNA mismatch distribution. Human Biology, 66: 591-600.

Indu, M., Ambili, T.R. and Manimekalan A. 2012. In sillico analysis of the molecular phylogeny of Siluriformes inferred from mitochondrial $\mathrm{CO} 1$ gene. International Journal of Advanced Life Sciences 5 (1): 7178.

Keskın, E. and Atar, H.H. 2013. DNA barcoding commercially important fish species of Turkey. Molecular Ecology Resources, 13(5): 788-97.

Marshall, E. 2005. Taxonomy. Will DNA bar codes breathe life into classification? Science, 307: 1037.

Na-Nakorn, U., Kamonrat, W. and Ngamsiri, T. 2004. Genetic diversity of walking catfish, Clarias macrocephalus, in Thailand and evidence of genetic introgression from introduced farmed C. gariepinus. Aquaculture, 240 (1-4): 145-163.

Nei, M. 1987. Molecular Evolutionary Genetics. Columbia University Press, New York.

Nelson, J.S. 2006. Fishes of the World. Edn 4, John Wiley \& Sons, USA, p. 163.

Ramos-Onsins, S.E., Rozas, J. 2002. Statistical properties of new neutrality tests against population growth. Molecular Biology and Evolution, 19(12): 2092-100. 
Rozas, J., Sánchez-DelBarrio, J.C., Messeguer, X. and Rozas R. 2003. DnaSP. DNA polymorphism analyses by the coalescent and other methods. Bioinformatics, 19(18): 2496-2497.

Tajima, F. 1989. Statistical method for testing the neutral mutation hypothesis by DNA polymorphism. Genetics 123(3): 585-595.

Tamura, K., Stecher, G., Peterson, D., Filipski, A., Kumar, S. 2013. MEGA6: Molecular Evolutionary Genetics Analysis Version 6.0. Molecular Biology and Evolution, 30(12): 2725-2729.

Teugels, G.G., Ozouf-costz, C., Legendre, M. and Parrent M 1992. A karyological analysis of the artificial hybridization between Clarias gariepinus (Burchell, 1822) and Heterobranchus longifilis Valenciennes, 1840 (Pisces; Clariidae). Journal of Fish Biology 40 (1): 81-86.

Thompson, J.D., Higgins, D.G. and Gibson, T.J. 1994. CLUSTAL W: improving the sensitivity of progressive multiple sequence alignment through sequence weighting, position-specific gap penalties and weight matrix choice. Nucleic Acids Research, 22(22): 4673-4680.

Vitule, J.R.S., Umbria, S.C. and Aranha, J.M.R. 2006. Invasion note: Introduction of the African catfish Clarias gariepinus (BURCHELL, 1822) into Southern Brazil. Biological Invasions, 8: 677-681.

Wong, L.L., Peatman, E., Lu, J., Kucuktas, H., He, S., Zhou, C., Na-Nakorn, U. and Liu, Z. 2011. DNA barcoding of catfish: species authentication and phylogenetic assessment. PLoS One, 6(3): e17812.

Yu D.B., Chen R., Kaleri, H.A., Jiang, B.C., Xu, H.X. and Du, W.X. 2011. Testing the utility of mitochondrial cytochrome oxidase subunit 1 sequences for phylogenetic estimates of relationships between crane (Grus) species. Genetics and Molecular Research, 10 (4): 4048-62.

Zhang, Z-Q. 2011. Animal biodiversity: An outline of higher-level classification and survey of taxonomic richness. Zootaxa, 3148: 7-12. 